\title{
Mátyus Imre
}

\section{Königsberg hídjaitól az okos városokig}

\begin{abstract}
Absztrakt
Szúts Zoltán Online címú könyve arra tesz kísérletet, hogy áttekintse az internetes kommunikáció technológiatörténetének fôbb állomásait, illetve a hálózati kommunikáció elterjedésének társadalmi hatásait. A kötet több mint fél évszázad fontosabb eseményeit, jelenségeit, trendjeit vázolja fel, és olvasmányos tablót kínál az online kommunikáció és média jelentôsebb témáiról.

\section{Szerzó}

Mátyus Imre újmédia-kutató, a Szegedi Tudományegyetem Kommunikáció- és Médiatudományi Tanszékének tanársegéde, az SZTE Digitális Kultúra és Elméletek Kutatócsoportjának tagja, és a PTE Kultúratudományi doktori programjának doktorjelöltje. Fô kutatási területe az egyéni és kollektív identitások, közösségek online reprezentációja, illetve az új média társadalmi szerepének vizsgálata. Kiemelt érdeklődést tanúsít a szabad és nyílt forráskódú közösségek iránt.

E-mail: matyusimre@gmail.com

Honlap: http://matyusimre.hu
\end{abstract}

https://doi.org/10.31176/apertura.2019.14.2.7 


\section{Mátyus Imre}

\section{Königsberg hídjaitól az okos városokig}

[Szûts Zoltán: Online - Az internetes kommunikáció és média története, elmélete és jelenségei. Budapest, Wolters Kluwer, 2018. ISBN: 978963295778 4]

Az internet 2019-ben lépi át története elsô fél századát. Az ARPANET 1969-es beindítása óta a hálózati kommunikáció számtalan változáson ment át, és a mindennapi élet valamennyi területét befolyásolta. Ennek az elmúlt, bő ötven évnek az áttekintésére vállalkozott könyvével Szúts Zoltán. Az Online a szerzô szándékai szerint nem pusztán az elmúlt félszázad technikatörténeti áttekintése az internetes kommunikációval kapcsolatban, hanem az infokommunikációs eszközök és hálózatok társadalmi hatásainak vázlatos bemutatása is. A könyv a hálózati kommunikáció elméleti és technikai gyökereitôl a kortárs mobileszközök világának kiemelten fontos jelenségeiig vezeti az olvasót.

A kötet egy olyan átfogó internettörténeti munka kíván lenni, mely képet kínál az online kommunikációról mind infrastrukturális, mind a társadalmi praxisok szempontjából. A szerző célkitǔzése szerint azt igyekszik áttekinteni, hogyan ágyazódik a technológia a kulturális rendszerekbe, milyen hatással van a társadalomra. Szúts Zoltán ezzel egy olyan hiányt pótol a hazai internettudományos publikációk körében, melyet már korábban megjelent könyve, $A z$ internet metaforái, illetve publikációi próbáltak részben betölteni. Ahogyan arról a kötet bevezetôjében beszámol, az Online valójában egy másfél évtizedes kutatói munka eredménye, mely az internetes kommunikáció számos területére, jelenségére kiterjedt. Az internetet tudományos eszközként, gazdasági és médiaplatformként, valamint a személyközi interakciók tereként csakúgy bemutatja, mint kulturális alkotásként, új zsánerek és tartalmak tárházaként, a tudás és emlékezet új helyeként.

Bár mind folyóiratcikkek, mind könyvfejezetek formájában napvilágot láttak már magyarul szemelvények az internet történetéből, illetve számos (és egyre növekvô számú) forrást találunk az online kommunikáció és média jelenségeinek vizsgálatáról, eleddig nem született olyan mû, mely az Online-hoz hasonló feladatot vállalt volna magára. Az utóbbi években ugyan találkozhattunk az újmédia elméleti kereteit összefoglaló kötettel Andok Mónika (2015) tollából, vagy a kortárs internet legfontosabb tendenciáit, trendjeit áttekintố munkával Fehér Katalintól (2016), de Szúts Zoltán könyvének tartalmi sokszínúségét ezek a kiadványok nem közelítették meg. A szélesebb értelemben vett internettudomány (internet studies) már nem felfedezetlen vidék a hazai társadalomtudományos érdeklődés számára sem, de mindenképpen szükség volt egy ilyen jellegú áttekintô, kánonformáló látlelet, történeti áttekintés megszületésére. 


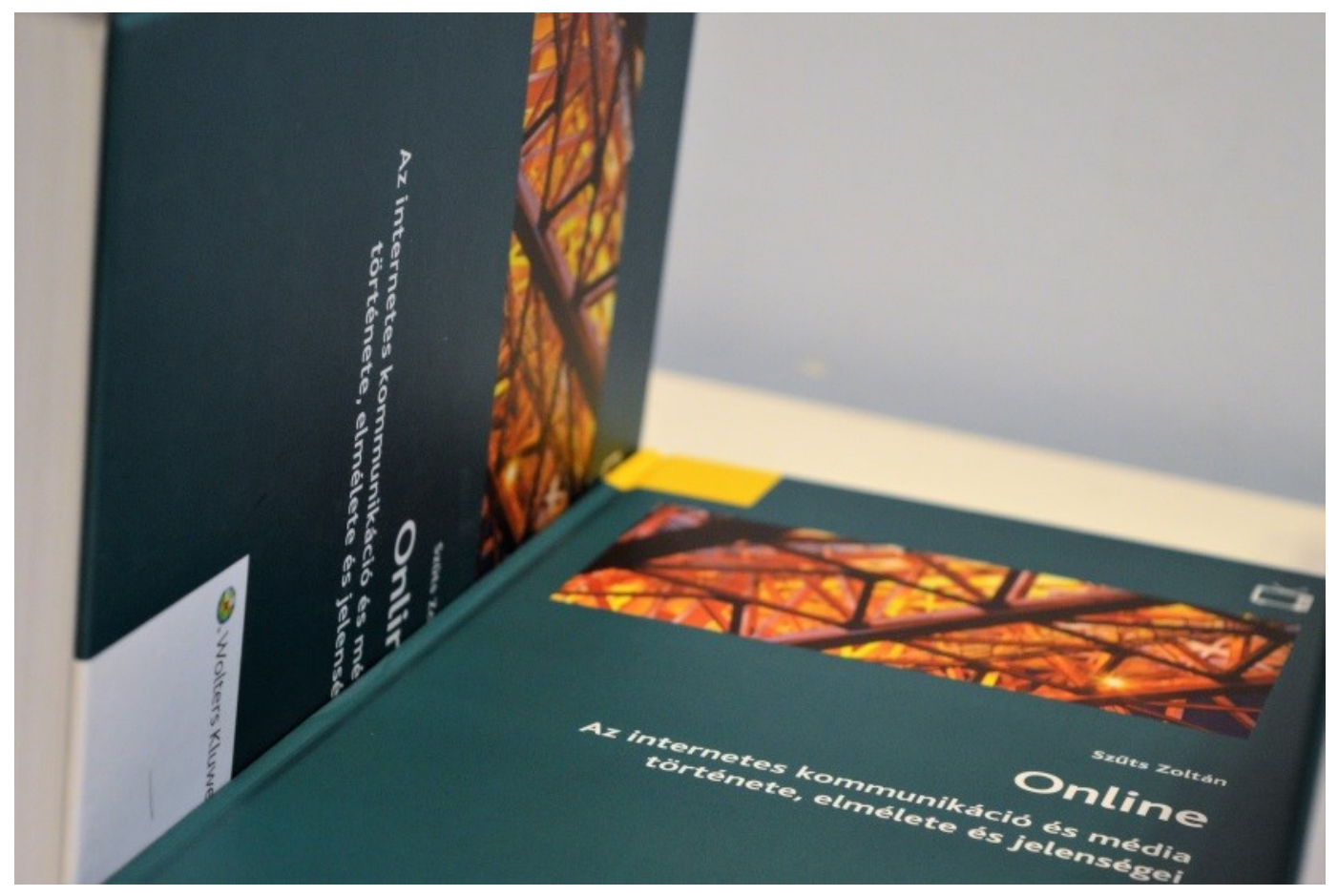

Nincs könnyú helyzetben, aki olyan nagyszabású munkára szánja el magát, mint az internet technológiai és társadalomtörténeti tablójának elkészítése. A terület kiterjedtsége, gyors változásai szinte lehetetlenné teszik a teljes és idôszerú lenyomatkészítést. S bár a külföldi szakirodalom viszonylag széles körben tárgyalja a hálózati társadalom első 30-40 esztendejének történetét, a kortárs jelenségekhez közelítve egyre inkább töredékes, esetleges leírásokkal találkozunk csupán. Szúts Zoltán maga is felismeri, és tudatosan reflektál erre az alapvetô problémára, mely szükségszerûvé teszi a bemutatott jelenségek, innovációk, mérföldkövek valamelyest önkényes kiválasztását. Szerencsére azonban a szerző választásai megfelelően mérlegeltek - a kötetben tárgyalt kérdések logikusan és érdemben illeszkednek az internetes kommunikáció történetének fô szálához/szálaihoz.

A könyv egyik fontos erénye - amellett, hogy remekül summázza a külföldi források eredményeit az internet történetével, társadalmi hatásaival kapcsolatban -, hogy igyekszik kitekinteni a középeurópai, illetve a hazai gyakorlatokra is. Igaz ugyan, hogy ezek csak viszonylag kis részét képezik a kötetnek, de ahogyan a szerzó is rámutat, a hazai internettörténet feldolgozása mindössze néhány éve kezdôdött meg, s részletes eredményei egyelőre váratnak magukra. 
Összességében az Online - a szerzô tudatos választása alapján - olyan technológia- és médiatörténeti kézikönyv, mely az infokommunikációs technológia változásainak regisztrálása, kronológiai rendezése mellett annak paradigmaváltó potenciálját is igyekszik bemutatni. A könyv jól szemlélteti azt a folyamatot, ahogyan egy erôforrás- és információmegosztásra kidolgozott, tudományos célokra használt technológia lassan átszőtte az üzleti életet, a professzionális médiumok világát, majd gyökeret vert az otthonokban és a felhasználók mindennapi életében. A szúk, szakmai felhasználástól az okoseszközös termelô felhasználók (prosumerek) világáig vezetô történet ez számos érdekes mellékszállal, érdekfeszítô kérdésekkel.

E recenzió címe a kötetet keretezô két témából származik. A „nulladik” rész Leonard Euler gráfelméleti megfejtésével kezdôdik, melyben a tudós matematikailag bizonyította, hogy a 18. század eleji Königsberg városa nem járható be úgy, hogy minden hídján csak egyszer haladjon át a sétáló polgár. $\mathrm{Az}$ „X.” rész utolsó témája voltaképp visszatérés a város hálózatához, bár az okos városok esetében talán inkább a hálózat városáról beszélhetnénk. S nem ez az egyetlen keret, ismétlődố szerkezeti minta a kötetben - az egyes részek elején többnyire olyan kiemelkedô személyek bemutatásával találkozunk, akik az adott témakör szempontjából kiemelten fontosak, a részek lezárásaként pedig rövid áttekintést kapunk az elôzô fejezetekben megjelenô esetek, technológiák társadalmi hatásairól.

A kötet öt nagyobb részre és ötvennégy hosszabb-rövidebb fejezetre bomlik. A "nulladiknak" keresztelt rész az internet megjelenését elôkészítô technológiai fejlesztések és elméleti keret leírása. Ezt követốn az elsố és második rész az internet eddigi történetének két fontosabb szakaszát mutatja be. Elôbb az 1969 és 1993 közötti idôszak kezdeti hálózatfejlesztését, az ARPANET és a globális internet kialakulását követhetjük végig, majd a második rész a világháló ( world-wide web) születésével, elsô évtizedével és a kommunikációra gyakorolt hatásaival foglalkozik. A harmadik rész az újmédiához kapcsolódó egyfajta attitûdváltást, a web 2.0-ként jelzett idôszak fejleményeit, társadalmi és kulturális hatásait járja körül a kortárs mobilkommunikációval bezárólag. Az utolsó, „X. rész” elsôsorban olyan kérdéseket, jelenségeket vázol fel az olvasó számára, melyek már most hatással vannak mindennapjainkra, de vélhetóen még nagyobb szerepük lesz a közeljövôben.

Ahogyan talán ezen rövid áttekintésból is kitûnhet, az Online felépítése makroszerkezetében kronológiai rendezố elvet követ, ugyanakkor a szerzô - a téma által indokolt esetekben - ettôl helyenként eltér, elkalandozik a szigorú idôvonaltól, de ezen eltérések minden esetben jól indokolhatók az érthetôség javításának szempontjával.

Egy recenziónak nem lehet célja az eredeti munka felmondása, és egy ilyen volumenú alkotásnál ezt meg sem kísérelném. Ezért az alábbiakban arra vállalkozom, hogy kiemeljek néhány lényeges pontot, vezérelvet, tanulságot a kötet egyes részeiból.

Az Elôszó, illetve a Bevezetés kellô részletességgel mutatja be azt az elméleti környezetet és perspektívát, melyben a mú megszületett. Szúts részletesen foglalkozik a hatalmas elemzési anyag 
kiválogatásának, egységbe szerkesztésének nehézségeivel, és már ez a fajta önreflexív problémafelvetés is kiemelten hasznossá teszik a könyvet az internettel kapcsolatban született hazai szövegek között. A szerzô hangsúlyozott szándéka az, hogy ne csupán a technológia fejlôdésének menetét vázolja az olvasó számára, hanem bemutassa azokat a társadalmi hatásokat, melyeket az infokommunikáció fejlódése, terjedése indukált a társadalom különbözô rendszereiben:

Abban, hogy miként alakult az internetes kommunikáció és média története, nem kizárólag technológiai, sokkal inkább társadalmi, kulturális, vagy éppen felhasználói faktorok játszottak szerepet. (Szúts 2018: 21)

A kötet egyik erôssége az, hogy igyekszik minél szélesebb körben feltárni azokat a társadalmi változásokat, igényeket, gyakorlatokat, melyek a technológia alakulásában, felhasználásában szerepet játszottak. Jól demonstrálja, hogy az innovációk fejlôdése, terjedése nagyban függ a technológiát birtokba vevố társadalmi környezettôl.

A Bevezetés leginkább üdvözlésre méltó eleme az áttekintés az internettudomány (internet studies) interdiszciplináris területérôl. Ez a rész önmagában is megmutatja, mennyi terület, értelmezési keret, problémafelvetés és kutatási módszer találkozik az internet vizsgálata kapcsán, ami vitathatatlanul jelzi az infokommunikációs eszközök komplex társadalmi beágyazottságát. Számos diszciplína igyekszik saját eszközeivel, saját kérdéseit vizsgálni az internet kapcsán, s ezen eredmények összessége képes csupán egyfajta átfogó képet nyújtani a jelenségegyüttes összetettségérôl, melyben a szerzố példás kitartással igyekszik valamilyen követhetô rendszert alkotni az olvasó számára.

A könyv „nulladik” része az internet kialakulásának, technológiai alapfeltételeinek kialakulásával foglalkozik. A szerző itt röviden áttekinti a hálózatelmélet néhány jelentôsebb gondolatát, mérföldkövét, a kommunikációs hálózatok generációit, valamint részletesebben foglalkozik a számítógépek történetével az 1940-es évek elektronikus számítógépeitôl a kortárs okostelefonokig. E rész különösen azért lehet fontos, mert Szúts Zoltán nem szorítkozik pusztán a nyugati (elsôsorban amerikai) fejlesztések bemutatására, hanem megemlékezik az európai, a keleti blokk, illetve konkrétan a magyar számítástechnika kezdetei küzdelmeirôl is. Különösen fontos e részben a felhasználók munkavégzéssel, szabadidő eltöltésével kapcsolatos praxisaiban bekövetkezett paradigmaváltás - a személyi, illetve otthoni számítógép „domesztikációjának” kiemelése. Szúts itt is igyekszik a technológiatörténeti elbeszélést a felhasználók társadalmi gyakorlataiban elhelyezni és rámutatni azok jelentôségére az informatika szúkebb körein túl.

A könyv következő nagyobb tartalmi egysége (Első rész) már a globalizálódó infokommunikációs hálózatok korai történetét mutatja be az ARPANET kialakulásától (1969) a világháló megszületéséig (1991-1993). Szúts megemlékezik azokról a tudósokról, akiknek kulcsszerepe volt a hálózati kommunikáció alapjainak létrehozásában, bemutatja az ARPANET történetét, bóvülését, Internetté való átalakulásának folyamatát, és szót ejt más, kisebb volumenú kezdeményezésekrôl, 
kísérletekrôl is (mint amilyen a Cyclades, a Cybersyn, vagy a francia Teletel/Minitel hálózat). A megfelelôen részletes bemutatást itt is a társadalmi hatások kivonatos bemutatása zárja, mely jól leírja azt a folyamatot, ahogyan a hálózati kommunikáció alakulása az 1980-1990-es évekre egyre nagyobb hatással volt a nyugati kultúrák mindennapjaira a gazdaság szféráján túl is. Ez az az idôszak, amelyben a számítástechnika és az internet használata átlépi a tudományos és gazdasági élet határait, és egyre markánsabban jelenik meg a mindennapi életben az információszerzés új formájaként.

Az Online második része a világháló megjelenésére és hatásaira koncentrál - elsôsorban a 2010-es évek derekáig. Az adott részt megnyitó arcképcsarnokban a hipertext és a hipertextualitásra épüló világháló néhány fontos előfutárát, illetve alkotóját mutatja be a szerzô Vannevar Bush, Theodore Nelson, Douglas Engelbart és Tim Berners-Lee személyében. A könyv ezen szakasza azokat a jelentôs momentumokat helyezi elôtérbe, melyek a számítógépes hálózatokat egyre markánsabban kiemelték korábbi, szúkebb felhasználói körükből, és a széles közönség számára is érdekes médiafelületté, platformmá változtatták az internetet. A technológia fejlôdése mellett egyre jellemzóbbé vált a felhasználói igényekhez jobban alkalmazkodó szolgáltatások, tartalmak, valamint az ezek kielégítését célzó gazdasági modellek megjelenése. Az 1990-es évek technológiai paradigmaváltása nem pusztán a tartalmak vagy az üzleti élet, hanem a fogyasztói minták, az információhoz való hozzáférés és annak megôrzése szempontjából is komoly változást jelentettek. Szúts Zoltán hatékonyan mutatja be, hogyan válik egyre inkább megkerülhetetlenné, a kortárs kultúra inherens részévé a hálózati kommunikáció. Az online nyilvánosság, közösségek, piacterek, az új, digitális gazdaság kihívásai társadalmi, jogi és gazdasági téren is jelentkeznek, s ez mind visszaköszön az Online oldalain.

Külön kiemelném, hogy a kötet második része foglalkozik legbehatóbban azzal a paradigmaváltással, mely a tapasztalatok fényében drasztikusan átalakította a kommunikáció személyközi és tömegkommunikációs (mediális) aspektusait egyaránt. Az új platformok, új technológiai affordanciák jelentősen befolyásolták a nyelvhasználat, a tudás, a közösségek, illetve emberi kapcsolatok kialakításának és fenntartásának területeit. Szúts bemutatja ugyan a technológiai változásokkal kapcsolatos optimista és pesszimista kritikákat, olvasatokat is, ô maga azonban igyekszik semleges maradni, egyfajta „technorealista” álláspontot képviselni. S bár a munkában helyenként megjelenik az óvatos optimizmus, illetve a tapasztalatokból származó elővigyázatosságra intés, a szerzô nem fogalmaz meg értékítéletet, nem egyszerúsíti a IKT társadalmi hatásait egyértelmú folyamatokra.

A könyv harmadik része a kortárs internet, a web 2.0, illetve a közösségi média világába kalauzolja az olvasót. Ahogyan közeledünk a jelenhez, a kötet egyre kevésbé követ szigorú kronológiai rendet. Ebben a részben már sokkal inkább a kiemelt jelenségek, változások központozzák a szöveg szerveződését, s kevésbé az idóbeli sorrendiség. Ez azonban teljesen érthetô, hiszen az itt tárgyalt trendek, tendenciák, események olyan sok szálon kapcsolódnak egymáshoz, s gyakran egyszerre történnek, hogy ezek komplexitását, szinkronitását szinte lehetetlen megfelelóen visszaadni egy lineáris narratívában. Szúts Zoltán ebben a részben nem csak a közösségi média 
csúcsragadozóinak, a Facebook, a Twitter, a YouTube vagy az Instagram bemutatására vállalkozik, hanem olyan mélyebb átalakulásokat is igyekszik bemutatni, mint a politikai aktivitás, a jogi szabályozás vagy akár a vizualitás szférájában bekövetkezô változások. Sok és valóban fontos témát vet fel ebben a részben, a nyilvánosság szerkezetváltozásától, a felejtéshez való jogon át, az augmentált valóság szerepéig, melyek mind-mind külön könyveket is megtölthetnének.

Különösen hasznosnak találom az influencerekkel, a szelfivel, az internetes mémekkel, valamint a szerzô leleményes elnevezésével élve - „15 klikk hírnévnek” a rövid bemutatását; ezek nagyszerü kiindulópontot jelenthetnek a kortárs újmédiával kapcsolatos dolgozatok számára.

Az Online utolsó, „X-ik” része a jelen és a jövô kihívásaival foglalkozik. Döntôen olyan területek, problémák, alkalmazások jelennek meg itt, melyekkel már ma is találkozunk az internethasználat során, de várhatóan sokkal nagyobb hatásuk lesz a társadalomra a közeljövôben. Ilyen témaként vetôdik fel az álhírek, a megbízhatóság megkérdôjelezôdésének problémája, a mesterséges intelligencia, a gépi tanulás és a chatbotok lehetséges hatásai, a big data átfogó gazdasági paradigmaváltó potenciálja, vagy a közösségek gazdasági hasznának kiaknázása (legyen szó crowdsourcingról vagy a közösségi gazdaságról [sharing economy]). Szúts Zoltán remekül ráérez, és kiemeli a generáció mint kollektív megkülönböztetés kortárs problémáját, az információs/digitális írástudással, médiahasználati, felhasználói praxisokkal kapcsolatos, életkori csoportok szerinti általánosítások hamisságát. Ahogyan fogalmaz:

Az információs társadalom tagjai - függetlenül attól, mely generációhoz tartoznak - már szimbiózisban élnek a számítógépeikkel, anyanyelvük a hálózati, az online használt nyelv. (Szúts 2018: 436)

S bár mindig akadnak különbségek az újdonságokra fogékonyabb, korai adaptálóként viselkedô fiatalok, illetve a kevésbé nyitott, lassabban alkalmazkodó idősebb korosztályok között, a technológia ismeretében, használatában mutatkozó különbségek nem redukálhatók pusztán korcsoportok közötti különbségekre; az infokommunikációs technológia hatásai nem általánosíthatók generációk szerint. 
A társadalomtudományos kutatás egyébként is jellemző lassúsága különösen szembetûnô olyan területeken, ahol a társadalmi hatások, tartalmi vagy szerkezeti változások napi szinten megtapasztalhatók. Az Online is jól példázza azt a tapasztalatot, hogy hiába tûnik az elmúlt két-két és fél évtized az eddigi történelem talán legjobban dokumentált idôszakának, a változások ütemeés a rendelkezésre álló információk feldolgozhatatlan mennyisége nehézkessé teszi az internetújabb fejleményeinek megfelelő értékelését, értelmezését, s a mindennapi érintettség,lezáratlanság akadályozza a jelenségek pontos elemzését. S míg egyre több forrással rendelkezünkaz internet korai történetérôl (elsôsorban az Amerikai Egyesült Államok szemszögéből, de épp azelmúlt 8-10 évben kezdődött el a „nemzeti internettörténelmek” feltárása is), a kétezres évekdereka és a jelen közötti idôszak kevésbé pontosan feldolgozott. Szúts Zoltán munkája már csakezért is példaértékú törekvés, hisz mindennek ellenére képes jó áttekintést nyújtani és koherensképet kialakítani a net fél évszázadának legfontosabb momentumairól.

Szûts Zoltán Online címú munkája több szempontból is figyelemre méltó könyv. Nem csupán azért, mert hatalmas vállalás az internet történetének, kommunikációs jelenségeinek, változásainak kivonatát adni, hanem azért is, mert a kortárs társadalmi hatásokkal kapcsolatos, feldolgozott tapasztalataink egyeloore korlátozottak. Ez a könyv mindenképpen példátlan terjedelmú és összetételú áttekintése az online kommunikáció eddigi történetének, egy igen összetett tabló azokról a személyekrôl, jelenségekrôl, eseményekrôl, technológiákról és trendekrôl, melyek döntően befolyásolták, illetve továbbra is befolyásolják mindennapjainkat. A felvetett témák, és a befektetett munka mennyisége egyaránt igazán impozáns.

Szintén dicséretes a szerzô azon törekvése, hogy a technológia fejlődésének történeti vázlatán felül társadalmi lenyomatot, hatásvizsgálatot végezzen. A kötet különbözô részeiben, fejezeteiben átfogó képet kaphatunk azokról a tendenciákról, melyek túlmutatnak a technológia használatának körein, és a kortárs társadalom mélyebb átalakítását eredményezik. Mindezt Szúts Zoltán úgy végzi el, hogy közben izgalmas, olvasmányos, laikusok számára is jól érthetô szöveget alkot, mely óvakodik a szélsôséges állásfoglalásoktól és a prédikációtól.

A könyvben emellett számos jól kiválasztott, érthetôen és olvasmányosan leírt példát találunk. Ezek nem pusztán a technológiai fejlesztések alapvetô megértéséhez, hanem azok nagyobb rendszerbe helyezéséhez is segítséget nyújtanak.

A kötet szerteágazó tartalma ugyanakkor érthetôen befolyásolja annak szerkezetét is, és ha valamilyen téren kritikával illethető a könyv, hát ez lenne az. Természetesen tisztában vagyok azzal, hogy minden jelentôs vagy annak értékelt esemény, személy, fejlesztés, trend beemelése csaknem lehetetlenné (és egészen biztosan gyorsan túlhaladottá) tenné a munkát, és inkább reményként, semmint szemrehányásként emelem ki, hogy a könyvben akadnak olyan részek, melyeket a jövôben érdemes lehet bővebben kidolgozni. A rendkívüli számú téma, eset, esemény felvetése és azok összekapcsolódása olykor igencsak megnehezíti a lineáris történetmesélést, mely helyenként azzal jár, hogy egyes fejezetek és az alájuk rendelt részfejezetek kapcsolata nem feltétlenül túnik egyértelmúnek. (Példa erre a 3. rész 14. fejezete, melyben az emoticonokról és 
emojikról szóló fejezetbe részfejezetként beágyazódik az Independent nyomtatott verziójának megszûnésérôl, és a BBCII! televíziócsatorna online környezetben való „feloldódásáról” szóló alfejezet.) Ugyancsak a tartalmi sokszínúség eredménye az is, hogy néhány igazán érdekfeszítônek tûnố téma (például a sharing economy vagy az okosvárosok), melyekrôl szívesen olvasnánk bôvebben is, csak röviden kerül terítékre.

Mindezek fényében azonban az Online egy elismerésre méltó összefoglalót nyújt az internet, és társadalmi hatásainak eddigi történetérôl. A kézikönyv nyelvezete, felépítése, tartalmi sokszínúsége rendkívül jól használhatóvá teszi a felsôoktatásban az információs társadalom, illetve az újmédia kérdéseivel kapcsolatos kurzusok számára. Ugyanakkor bárki, aki érdeklődik az online kommunikáció története és jelenségei, az IKT társadalmi beágyazottságának, hatásainak kérdései iránt, haszonnal forgathatja.

\section{Irodalomjegyzék}

- Andok Mónika: Digitális média és mindennapi élet: konvergencia, kontextus, közösségi média. Budapest, L'Harmattan, 2015.

- Fehér Katalin: Digitalizáció és új média: trendek, stratégiák, illusztrációk. Budapest, Akadémiai Kiadó, 2016. https://doi.org/10.1556/9789630597432

- Szúts Zoltán (2018): Online - Az internetes kommunikáció és média története, elmélete és jelenségei. Budapest, Wolters Kluwer. 
(C) Apertúra, 2019. tél | www.apertura.hu

webcím: https://www.apertura.hu/2019/tel/matyus-konigsberg-hidjaitol-az-okos-varosokig/

https://doi.org/10.31176/apertura.2019.14.2.7

$$
\text { (2) opertúro }
$$

